\title{
Stabilization of Black Cotton Soil by Using GGBS, Lime and Nano-Silica
}

\author{
Mahesh Vastrad $^{1 *}$, M. Karthik ${ }^{2}$, Varsha Dhanavandi ${ }^{3}$, M. S. Shilpa ${ }^{4}$ \\ ${ }^{I}$ M.Tech. Student, Department of Construction Technology \& Management, Dayananda Sagar College of \\ Engineering, Bangalore, India \\ ${ }^{2,3,4}$ Assistant Professor, Department of Construction Technology \& Management, Dayananda Sagar College of \\ Engineering, Bangalore, India \\ *Corresponding author: maheshvastrad04@gmail.com
}

\begin{abstract}
Soil is known of their geotechnical properties and suitability as base, sub-based and sub-grade materials for road construction with the increase in population reduce the land availability. In current situation there is increasingly more development of structures and other structural building structures must be completed on less strength or poor soil. Black cotton soil is found in Madhya Pradesh, Karnataka, Maharashtra Andhra Pradesh \& Tamilnadu covering an area of about 3.0 lakh sq. km in our nation. Black cotton soil is one of the largest soil stores of India, so for the reason need to increase its geotechnical properties and make it comfortable for the development reason. In pavement surface causes problems like cracking, rutting, patching, potholes and detoriation in the pavement surface. The development on black cotton soil (expansive soil) has consistently been a giving tough task for the specialists as the Road \& structure laying on black cotton soil breaks without any notice. Stabilization of soil by GGBS couldn't just take care of the issue of appropriate stabilization of black cotton soil, yet in addition settle the issue of removal of a modern waste for example GGBS. The properties of black cotton soil can be modified by stabilizing the soil with the use of additives or stabilizers like Lime (6\%), GGBS (30\%) \& Nano silica $(0.3 \%, 0.6 \% \& 0.9 \%)$. There is increase in various geotechnical properties like liquid limit, and plastic limit, compaction characteristics, unconfined compressive strength, CBR values and swelling pressure were determined. An experimental investigation is carried out to study the influence of admixture in soil with respect to the strength characteristics. In this comparative study laboratory tests such as Atterberg's limit, Compaction test, swelling index and California Bearing Ratio (CBR)\& Unconfined compressive strength (UCS)test were carried out for black cotton soil.
\end{abstract}

Keywords: California Bearing Ratio (CBR), Ground Granulated Blast Furnace Slag (GGBS), Lime, Nano-silica, Stabilization, Unconfined Compressive Strength (UCS).

\section{Introduction}

Soil is the essential component of this nature. Just imagine the world Without the soil it is only close to difficult to consider life on this planet. The term soil in soil designing is characterized as an unconsolidated material, formed by breakdown of larger rock into smaller particles that particle is soil. Soil is known of their geotechnical properties and suitability as base, sub-based and sub-grade materials for road construction with the increase in population reduce the land availability. In current situation there is increasingly more development of structures and other structural building structures must be completed on less strength or poor soil. Black cotton soil is found in Madhya Pradesh, Karnataka, Maharashtra Andhra Pradesh \& Tamilnadu covering an area of about 3.0 lakh sq. $\mathrm{km}$ in our nation. In pavement surface causes problems like cracking, rutting, patching, potholes and detoriation in the pavement surface.

The current study mainly focuses on Stabilization of soil by GGBS couldn't just take care of the issue of appropriate stabilization of black cotton soil. yet in addition settle the issue of removal of a modern waste for example GGBS. The properties of black cotton soil can be modified by stabilizing the soil with the use of additives or stabilizers like Lime (6\%), GGBS $(30 \%)$ \& Nano silica $(0.3 \%, 0.6 \%$ \& $0.9 \%)$.

\section{Literature Review}

A literature search focused on information pertaining to soil, lime, Nano-silica and waste like Ground Granulated Blast Furnace (GGBS) are used to improve the strength, bearing capacity of the soil and reduce shrinkage and Swelling index of the soil. This search involved domestic and international sources available from public agencies, industry, academic institutions, and other organizations.

Kavish S. Mehta et al. This study was undertaken to check the with the expanding of populace and the decrease of accessible land, increasingly more development of structures and other structural designing structures must be completed on feeble or delicate soil.

C. S. Nandhakumar et al. Soil stabilization is one of the change strategies used to improve the index property and designing properties of soil and has become the significant practice in development building which empowers the successful use of mechanical squanders as a stabilizer. Because of fast increment in populace, land is getting scant thus it is important to strengthen frail or tricky soil enough to withstand a wide range of burdens. This procedure of improving an on location (in-situ) soil's building properties is likewise alluded 
Volume-3, Issue-9, September-2020

\section{IJRESM journals.resaim.com/ijresm | ISSN (Online): 2581-5792 | RESAIM Publishing}

to as "soil adjustment" or "soil stabilization".

Sunil Pusadkar et al. Black cotton soil display high expanding and contracting when presented to changes in moisture content and consequently have been seen as generally irksome from designing contemplations. Black cotton soil is one of the significant soil stores of India, so there is a need of improving its geotechnical properties and make it reasonable for the development reason.

Mohammed Sameeuddin et al. Black cotton soil is considered as a tricky soil since it has less soundness, less shear strength, huge extension and shrinkage in volume brought about by their substitute growing and shrinkage with evolving season. Then again, Ground Granulated Impact Furnace Slag (GGBS), which is a side-effect of pig iron and steel industry mechanical waste, causes land contamination. In India more than 10 million tons of ground granulated impact furnace slag is delivered each year. In this paper, test study is directed on the stabilization of black cotton soil by Ground Granulated Impact Furnace Slag.

Mohammad Ali Pashabavandpouri et al. In soil site arranging, soil layers, applied as establishments of structures, establishments and subgrade, ought to have the option to withstand the heaps inside the scope of suitable distortions and move them to the ground, thus soil properties, for example, strength and deformability are noteworthy. Soil stabilization utilizing added substances in nanoscale can be applied as a strategy to improve soil designing qualities and strength. Lately, nanotechnology has generally and quickly been utilized in all science fields.

\section{A. Objectives of the study}

The essential destinations of investigation of black cotton soil are as following:

- Increase in bearing limit of Black Cotton Soil on expansion of lime.

- Different of Strength of soil at different water content.

- Effect of lime on CBR estimation of the soil.

- Effect of lime on Compressive strength of soil.

- The liquid limit and plasticity index of black cotton soil was increases.

- To reduce the Swelling pressure of soil.

\section{Materials and Methodology}

\section{A. Introduction}

This section of the paper discusses the procedures being conducted in the laboratory. Stabilization of soil by GGBS couldn't just take care of the issue of appropriate stabilization of black cotton soil, yet in addition settle the issue of removal of a modern waste for example GGBS. The properties of black cotton soil can be modified by stabilizing the soil with the use of additives or stabilizers like Lime (6\%), GGBS (30\%) \& Nano silica $(0.3 \%, 0.6 \% \& 0.9 \%)$. There is increase in various geotechnical properties like liquid limit, and plastic limit, Plasticity index, compaction characteristics, unconfined compressive strength, CBR values and swelling pressure were determined. An experimental investigation is carried out to study the influence of admixture in soil with respect to the strength characteristics. In this comparative study laboratory tests such as Atterberg's limit, Compaction test, swelling index and California Bearing Ratio (CBR)\& Unconfined compressive strength (UCS)test were carried out for black cotton soil.

\section{B. Materials utilized for the study}

1) Black cotton soil

Soil used in experimental investigation was a locally available black cotton soil from Amingad, Karnataka. The soil was classified as $\mathrm{CH}$ and based on FSI value the soil had high swell characteristic. Black cotton soil possesses great threat for the construction of the buildings due its less characteristics shear strength and high swelling characteristics. The structures on Black cotton soil (BC soil) bases develop undulations at the road surface due to loss of strength of the sub-grade through softening during monsoon. Due to its characteristics, it forms a very poor foundation material for road construction.

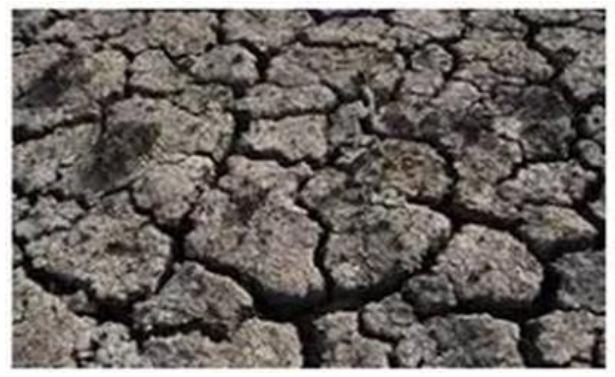

Fig. 1. Black cotton soil

\section{2) Lime}

In general, all lime treated fine-grained soils exhibit decreased plasticity, improved workability and reduced volume change characteristics. However, not all soils exhibit improved strength characteristics. It should be emphasized that the properties of soil lime mixtures are dependent on many variables. Soil type, lime type, lime percentage and curing conditions (time, temperature, and moisture) are the most important.

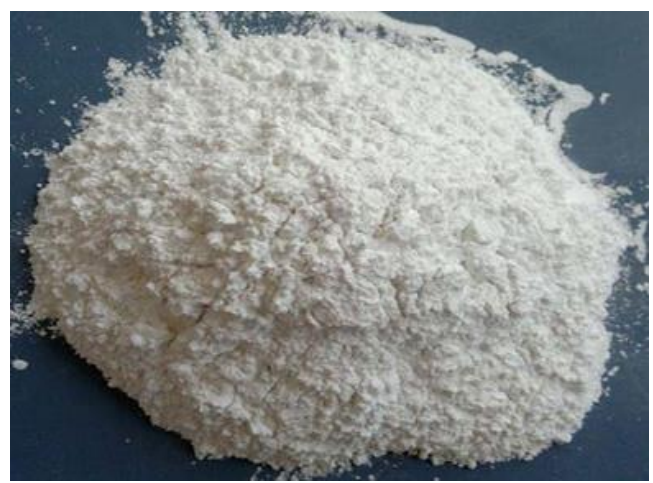

Fig. 2. Hydrated lime 
Volume-3, Issue-9, September-2020

\section{IJRESM journals.resaim.com/ijresm | ISSN (Online): 2581-5792 | RESAIM Publishing}

Table 1

Gradation Requirements

\begin{tabular}{|c|c|c|}
\hline Type course & Sieve size & Percent passing \\
\hline \multirow{4}{*}{ Base } & $1 \frac{1}{2}$ in. & 100 \\
\cline { 2 - 3 } & $3 / 4$ in. & $70-100$ \\
\cline { 2 - 3 } & No. 4 & $45-70$ \\
\cline { 2 - 3 } & No. 40 & $10-40$ \\
\cline { 2 - 3 } & No. 200 & $0-20$ \\
\hline Subbase & $11 / 2$ in. & 100 \\
\hline & No. 4 & $45-100$ \\
\hline & No. 40 & $10-50$ \\
\hline & No. 200 & $0-20$ \\
\hline
\end{tabular}

\section{3) Nano-silica}

The nano-silica powder which was utilized in the trial examination for stabilizing the black cotton soil was acquired from Adinath Industries having size $250 \mu$ shown in below fig.

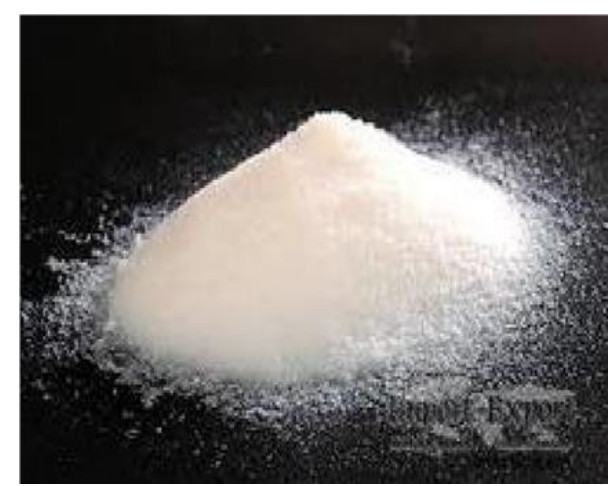

Fig. 3. Nano-silica powder

\section{4) Ground Granulated Blast Furnace Slag (GGBS)}

The blast furnace slag is produced as a by-product during the manufacture of iron in a blast furnace. Molten blast furnace slag has a temperature of $1300-1600 \mathrm{C}$ and is chilled very rapidly to prevent crystallization.

Ground-granulated impact furnace slag is gotten by extinguishing liquid iron slag from a shoot furnace in water or steam, to create a polished, granular item that is then dried and ground into a fine powder. The granulated material thus produced is known as granulated blast furnace slag. Blast furnace slag has a glassy, disordered, crystalline structure which can be seen by microscopic examination which is responsible for producing a cementing effect. Ground Granulated Blast Furnace Slag was gotten from JINDAL STEEL WORKS, situated at Bellary district of Karnataka. It is accessible at a pace of ₹200/- per ton.

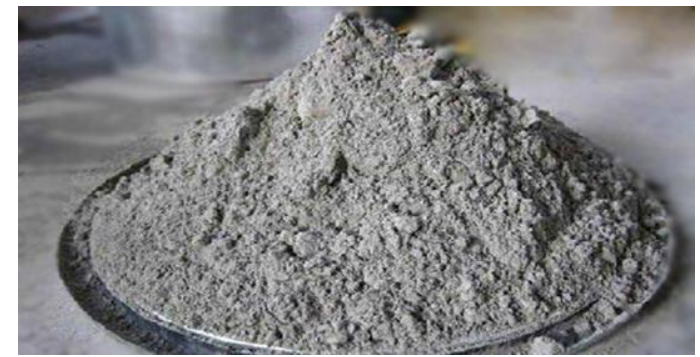

Fig. 4. Ground Granulated Blast Furnace Slag (GGBS)

\section{Methodology}

The gathered example of black cotton soil was tested in lab for the investigation of different engineering properties and the following tests were directed. At first the plastic limit, liquid test, shrinkage limit, Free Swelling Index, Sieve analysis, Unconfined Compressive Strength test and California Bearing Ratio tests are conducted on the black cotton soil without the adding any additives like of GGBS, lime \& Nano silica and the results are noted. The similar test is conducted for the Ground Granulated Blast Furnace Slag (GGBS) to collect engineering properties of the GGBS is it is very important to conducted further tests. From the Compaction test getting the values of optimum amount of GGBS. In addition, from the studies it was found that the optimum value of GGBS lie within the range of $10 \%-50 \%$. So from this range, test was conducted to study properties of soil. Then soil was mixed with different percentages of GGBS ranging from 5\% to $40 \%$ (i.e. $5 \% 10 \%$, $15 \%, 20 \%, 25 \%, 30 \%, 35 \%, 40 \%$ ) by dry weight of soil. After analysing the result of these tests, the optimum value of GGBS was found to be $30 \%$, at which the MDD is highest and OMC is relatively low compared to the other values. Lastly, the remaining tests apart from standard proctor test are conducted on black cotton soil mixed with optimum percentage of GGBS. After that conduct the CBR \& UCS test on soil with the different percentage of GGBS to the greater CBR \& UCS value. At some percentage of GGBS with soil gives larger CBR \& UCS value that percentage of GGBS mixed with Nano silica of percentage $(0.3 \%, 0.6 \%, 0.9 \%)$ and The remaining tests performed on the soil sample are as follows:
a) Specific gravity
b) Test for free Swell Index
c) Test for Shear strength of soil

1) California bearing ratio test

2) Unconfined Compressive Strength

The similar test is conducted for the lime to collect engineering properties of the lime is it is very important to conducted further tests. From the Compaction test getting the values of optimum amount of lime. In addition, from the studies it was found that the optimum value of lime lies within the range of $0 \%-9 \%$. So from this range, test was conducted to study properties of soil. Then soil was mixed with different percentages of lime ranging from $0 \%$ to $9 \%$ (i.e. $3 \% 6 \% 9 \%$ ) by dry weight of soil. After analysing the result of these tests, the optimum value of lime was found to be $0.6 \%$, at which the MDD is highest and OMC is relatively low compared to the other values. Lastly, the remaining tests apart from standard proctor test are conducted on black cotton soil mixed with optimum percentage of lime. After that conduct the CBR \& UCS test on soil with the different percentage of lime to the greater CBR \& UCS value. At some percentage of lime with soil gives larger CBR \& UCS value that percentage of lime mixed with Nano silica of percentage $(0.3 \%, 0.6 \%, 0.9 \%)$ and The remaining tests performed on the soil sample are as follows: 
a) Test for free Swell Index

b) Test for Shear strength of soil

1) California bearing ratio test

2) Unconfined Compressive Strength

After comparing the both CBR \& UCS values Which combination i.e. (soil+ GGBS+ Nano silica) or (soil+ Lime +Nano silica) gives FSI, CBR \& UCS values that combination should be considered for the project.

\section{Results and Discussions}

\section{A. Introduction}

In this investigation, different tests were led on stabilized soil and characteristic soil. After the basic test on soil conducted then next step will be similar test conducted for GGBS, lime and nano silica with different percentage which percentage gives better strength, higher CBR value, more UCS values and less OMC it will be taken to next procedure of testing. After complication of test on GGBS, lime and nano silica finalize the combination. Which combination gives better strength, higher CBR value, more UCS values and less OMC it will be considered for final project. Comparing the values of GGBS and lime which combination gives better strength, higher CBR value, more UCS values and less OMC that combination is mixed with $\%$ of nano silica.

Soil mix with GGBS $(10 \%, 20 \%, 30 \%, 40 \%)$ different percentage at which percentage gives better strength, higher CBR value, more UCS values and less OMC. That will be compare with lime. For Soil mix with lime $(3 \%, 6 \%, 9 \%)$ different percentage at which percentage gives better strength, higher CBR value, more UCS values and less OMC. It is Compare with the GGBS. In the combination which give favourable results for the project that will be considered. After very next better combination Some $\%$ of (GGBS or lime) mixed with some $\%$ of nano silica to get Soil mix with nano silica $(0.3 \%, 0.6 \%, 0.9 \%)$ different percentage at which percentage gives better strength, higher CBR value, more UCS values and less $\mathrm{OMC}$ that combination will be finalize for project.

B. Test on materials

1) The consistency limits

a) Plastic Limit (PL): The plastic limit (PL) is the moisture content at which a soil changes from being in a semisolid state to a plastic state.

b) Liquid Limit (LL): The liquid limit (LL) is characterized as the moisture content at which a soil changes from a plastic state to a liquid state.

c) Plasticity Index: The plasticity index (PI) is characterized as the contrast between the liquid limit and the plastic limit of a soil PI $=\mathrm{LL}-\mathrm{PL}$. The PI speaks to the scope of moisture contents inside which the soil carries on as a plastic solid.

2) Specific gravity

This test is done to decide the Specific gravity of fine-grained soil by density bottle technique according to IS.

\section{3) Compaction test}

The Proctor test was developed during the 1930s by R. R. Proctor, a field engineer for the Bureau of Waterworks and Supply, in Los Angeles, California. The procedure, which reproduces the in-situ compaction forms regularly performed during development of earth dams or banks, is the most widely recognized research centre test directed to infer the compressibility of soils.

\section{4) Free Swelling Index (FSI)}

Free swell index assurance of soil assists with recognizing the capability of a soil to expand which may require additionally itemized investigation in regards to growing and expanding pressures under various field conditions.

\section{5) California Bearing Ratio (CBR).}

The Californian Bearing Ratio (CBR) test is a penetration test used to assess the subgrade strength of streets and pavements. The consequences of these tests are utilized with the curves to decide the thickness of pavement and its part layers. This is the most generally utilized strategy for the design of adaptable pavement. The CBR test was created by the California Division of Highways to characterize and assess soil-sub level and base coarse materials for adaptable pavements. An exact test, the CBR test has been utilized to decide the material properties for pavement design. Experimental tests measure the strength of the material and are not a genuine portrayal of the versatile modulus.

\section{6) Unconfined compressive strength test (UCS)}

The shearing strength is regularly explored by methods for compression tests in which an axial burden is applied to the specimen and expanded until crack happens. It is the modification of Tri-axial test. No confining pressure is applied to the soil and there is only one stage in this test. Only axial stress is applied to the soil sample. If failure occurs in the soil due to the axial stress only. No rubber membrane is used in the test and it has only shear stress. It preferred only for the clayey soils and pressure applied only one vertical direction. The unconfined compressive strength is the force per unit area at which and unconfined cylindrical specimen of soil will fizzle in a basic compression test. In the event that the unit axial compression force per unit area has not arrived at a most extreme rise up to 20 percent axial strain, unconfined compressive strength will be viewed as the worth acquired at 20 percent axial strength. This test was led according to IS 2720 (Part10): 1973.

\section{Summary of test on materials}


Volume-3, Issue-9, September-2020

\section{IJRESM journals.resaim.com/ijresm | ISSN (Online): 2581-5792 | RESAIM Publishing}

Table 2

Summary on basic test on materials

\begin{tabular}{|c|c|c|c|}
\hline S.no. & Basic test & Results obtained & Materials \\
\hline 1 & Specific gravity & 2.65 & \multirow{10}{*}{ Black cotton soil } \\
\hline 2 & Atterberg's limits & & \\
\hline & Liquid limit & 58 & \\
\hline & Plastic limit & 28 & \\
\hline & Plasticity index & 30 & \\
\hline 3 & \multicolumn{2}{|l|}{ UCS Soil Classification } & \\
\hline 4 & Optimum Moisture Content & $31.06 \%$ & \\
\hline 5 & Maximum Dry Density & $1.4 \mathrm{gm} / \mathrm{cc}$ & \\
\hline 6 & California Bearing Ratio & 1.38 & \\
\hline 7 & Unconfined Compressive Strength & $1.0 \mathrm{~kg} / \mathrm{cm}^{2}$ & \\
\hline 8 & Specific Gravity & 2.74 & \multirow[t]{2}{*}{ GGBS } \\
\hline 9 & Weight/volume $\left(\mathrm{g} / \mathrm{cm}^{3}\right)$ & 1.39 & \\
\hline
\end{tabular}

Table 3

Summary of tests

\begin{tabular}{|c|l|l|l|l|l|l|}
\hline S. No. & \multicolumn{1}{|c|}{ Lab test } & \multicolumn{1}{|c|}{ Soil } & $\begin{array}{c}\text { Soil+30\% } \\
\text { GGBS }\end{array}$ & $\begin{array}{c}\text { Soil+6\% } \\
\text { lime }\end{array}$ & $\begin{array}{c}\text { Soil+0.6\% } \\
\text { nano silica }\end{array}$ & $\begin{array}{c}\text { Soil+30\% GGBS+0.6\% } \\
\text { nano silica }\end{array}$ \\
\hline 1 & Compaction & & & & & \\
& & \\
& OMC & 31.06 & 19.69 & 9.30 & 25.40 & 16.6 \\
& MDD & 1.4 & 1.54 & 1.83 & 1.83 & 1.96 \\
\hline 2 & California Bearing Ratio (CBR)\% & 1.38 & 2.64 & 2.32 & 5.76 & 6.16 \\
\hline 3 & Unconfined Compressive Strength (UCS) $\mathrm{kg} / \mathrm{cm}^{2}$ & 1.34 & 2.3 & 1.55 & 5.5 & 6.11 \\
\hline 4 & Free Swelling Index & 53.3 & 24.7 & 38 & 32 & 18 \\
\hline
\end{tabular}

D. Comparative study

1) Comparative study on compaction test

Table 4

OMC and MDD values for soil, $30 \%$ GGBS \& $6 \%$ lime

\begin{tabular}{|l|l|l|}
\hline \multirow{2}{*}{ Content } & \multicolumn{2}{|c|}{ Compaction curve } \\
\cline { 2 - 3 } OMC & \multicolumn{1}{c|}{ MDD } \\
\hline Soil & 31.06 & 1.4 \\
\hline Soil $+30 \%$ of GGBS & 19.69 & 1.54 \\
\hline Soil $+6 \%$ of lime & 9.30 & 1.83 \\
\hline
\end{tabular}

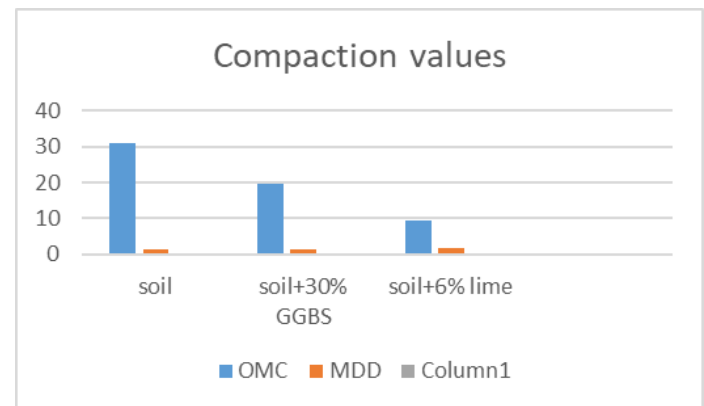

Fig. 4. OMC \& MDD values for soil, $30 \%$ GGBS \& $6 \%$ lime

From fig. 4 gives values of OMC \& MDD. combination of soil and lime has higher MDD value than the lime and OMC will be reduces more in the lime compare to GGBS so for this test Combination of lime and soil has highest values.

2) Comparative study on CBR test

Table 5 CBR values

\begin{tabular}{|l|l|}
\hline \multicolumn{1}{|c|}{ Content } & CBR Value (\%) \\
\hline BC SOIL & 1.38 \\
\hline BC SOIL +30\% GGBS & $\mathbf{2 . 6 4}$ \\
\hline BC SOIL + 6\% lime & 2.32 \\
\hline BC SOIL + 0.3\% nano silica & 4.31 \\
\hline BC SOIL + 0.6\% nano silica & $\mathbf{5 . 7 6}$ \\
\hline BC SOIL + 0.9\% nano silica & 5.4 \\
\hline
\end{tabular}

\section{CBR CHART}

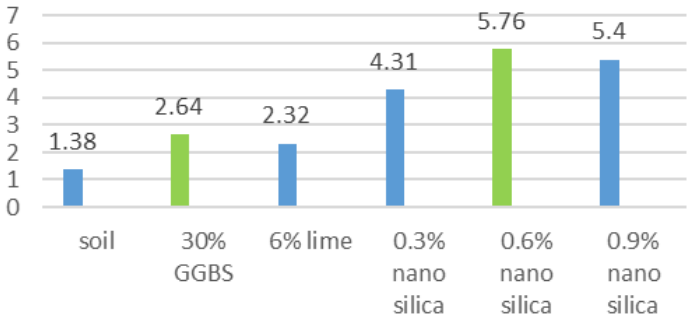

Fig. 5. CBR values with soil, $30 \%$ GGBS, $6 \%$ lime \& $(0.3 \%, 0.6 \%$ \& $0.9 \%$ ) nano silica

The values are obtained from the above fig on seeing those readings the combination of soil, $30 \%$ of GGBS \& $0.6 \%$ nano silica gives more CBR value than the combination of soil, $6 \%$ lime \& $0.6 \%$ nano silica so which combination gives the higher CBR value that combination considered.

\section{3) Comparative study on UCS test}

Table 6

UCS values at soil, $6 \%$ lime, $30 \%$ GGBS \& nano silica of $(0.3 \%, 0.6 \%, 0.9 \%)$

\begin{tabular}{|l|l|}
\hline \multicolumn{1}{|c|}{ Content } & UCS Value $\left(\mathbf{k g} / \mathbf{c m}^{2}\right)$ \\
\hline Soil $+\mathbf{0 \%}$ of GGBS & $\mathbf{1 . 3 4}$ \\
\hline Soil $+\mathbf{3 0 \%}$ of GGBS & $\mathbf{2 . 3}$ \\
\hline Soil $+6 \%$ lime & 1.55 \\
\hline Soil $+0.3 \%$ of nano silica & 5.4 \\
\hline Soil $+\mathbf{0 . 6 \%}$ of nano silica & $\mathbf{5 . 5}$ \\
\hline Soil $+0.9 \%$ of nano silica & 4.81 \\
\hline
\end{tabular}

The values are obtained from the fig. 6 on seeing those readings the combination of soil, $30 \%$ of GGBS \& $0.6 \%$ nano silica gives more UCS value than the combination of soil,6\% lime \& $0.6 \%$ nano silica so which combination gives the higher UCS value that combination considered. 
Volume-3, Issue-9, September-2020

\section{IJRESM journals.resaim.com/ijresm | ISSN (Online): 2581-5792 | RESAIM Publishing}

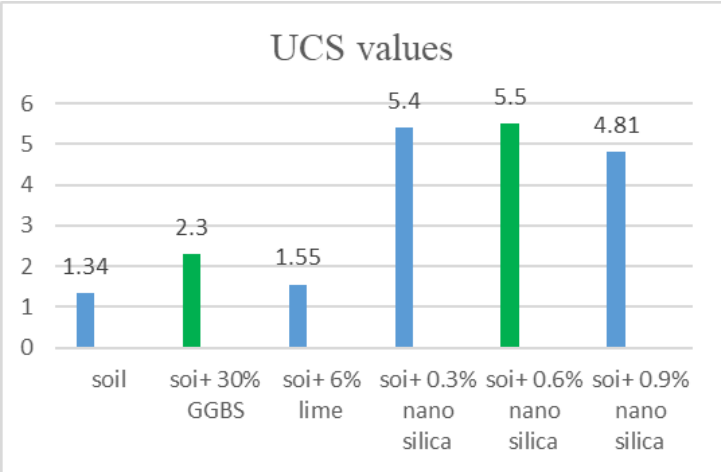

Fig. 6. UCS values at soil, $6 \%$ lime, $30 \%$ GGBS \& nano silica of $(0.3 \%$, $0.6 \%, 0.9 \%)$

4) Comparative study on free swelling index

Table 7

Free swelling index values for at soil, $6 \%$ lime, $30 \%$ GGBS \& nano silica of $(0.3 \%, 0.6 \%, 0.9 \%)$

\begin{tabular}{|l|l|}
\hline \multicolumn{1}{|c|}{ Content } & Free swell index value (\%) \\
\hline Soil & 53.3 \\
\hline Soil $+30 \%$ of GGBS & 24.7 \\
\hline Soil $+6 \%$ of lime & 38 \\
\hline Soil $+0.3 \%$ nano silica & 48 \\
\hline Soil $+0.6 \%$ nano silica & 32 \\
\hline Soil $+0.9 \%$ nano silica & 40 \\
\hline
\end{tabular}

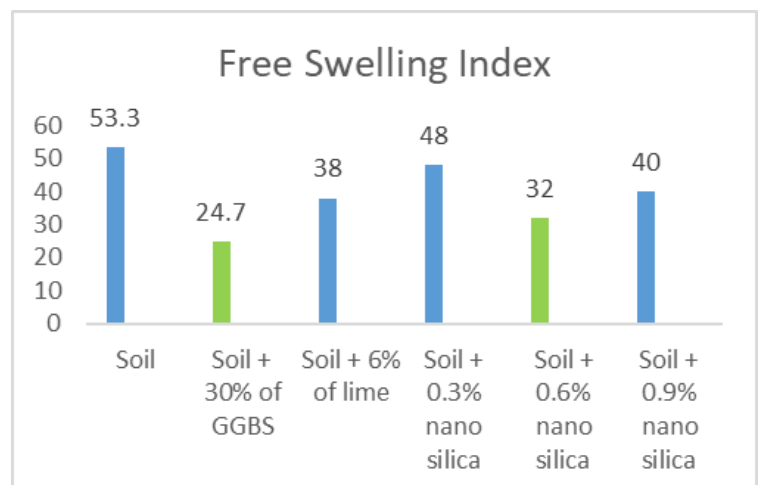

Fig. 7. Free swelling index for at soil, $6 \%$ lime, $30 \%$ GGBS and nano silica of $(0.3 \%, 0.6 \%, 0.9 \%)$

The values are obtained from the above fig on seeing those readings the combination of soil, $30 \%$ of GGBS \& $0.6 \%$ nano silica gives less FSI value than the combination of soil, $6 \%$ lime \& $0.6 \%$ nano silica so which combination gives the lower FSI value that combination considered.

5) Comparative study on soil with the combination of Soil, $30 \%$ GGBS\&0.6\% nano silica

Table 8

Compaction curve values for soil\& soil, 30\% GGBS\&0.6\% nano silica

\begin{tabular}{|l|l|l|}
\hline \multirow{2}{*}{ Content } & \multicolumn{3}{|c|}{ Compaction curve } \\
\cline { 2 - 3 } & OMC (\%) & MDD $\left(\mathbf{k g} / \mathbf{c m}^{2}\right)$ \\
\hline Soil & 31.06 & 1.4 \\
\hline Soil $+30 \%$ of GGBS $+0.6 \%$ nano silica & 16.60 & 1.76 \\
\hline
\end{tabular}

The values are obtained from the fig. 8 , on seeing those readings the combination of soil, $30 \%$ of GGBS \& $0.6 \%$ nano silica gives higher MDD value \& lower OMC than the combination of soil, $6 \%$ lime \& $0.6 \%$ nano silica so which combination gives the best value that combination considered.

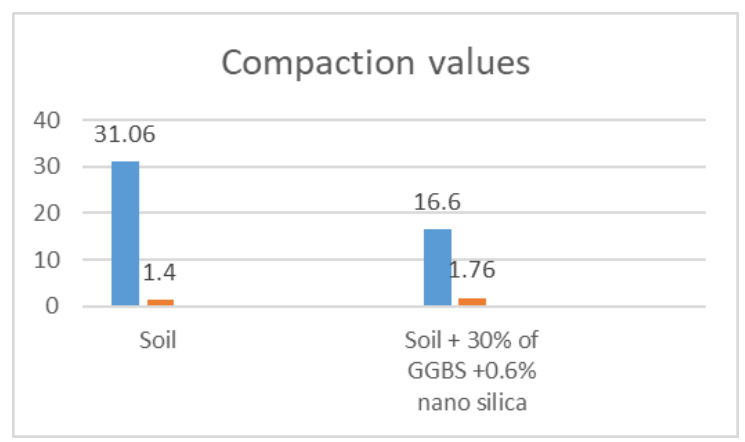

Fig. 8. Compaction curve values for soil \& soil, $30 \%$ GGBS \& $0.6 \%$ nano silica

6) Comparative study on CBR test

Table 9

CBR values for soil with soil, $30 \%$ GGBS \& $0.6 \%$ nano silica content

\begin{tabular}{|l|l|}
\hline \multicolumn{1}{|c|}{ Content } & CBR value (\%) \\
\hline BC SOIL & 1.38 \\
\hline BC SOIL +30\% GGBS +0.6\% NANO SILICA & 6.66 \\
\hline
\end{tabular}

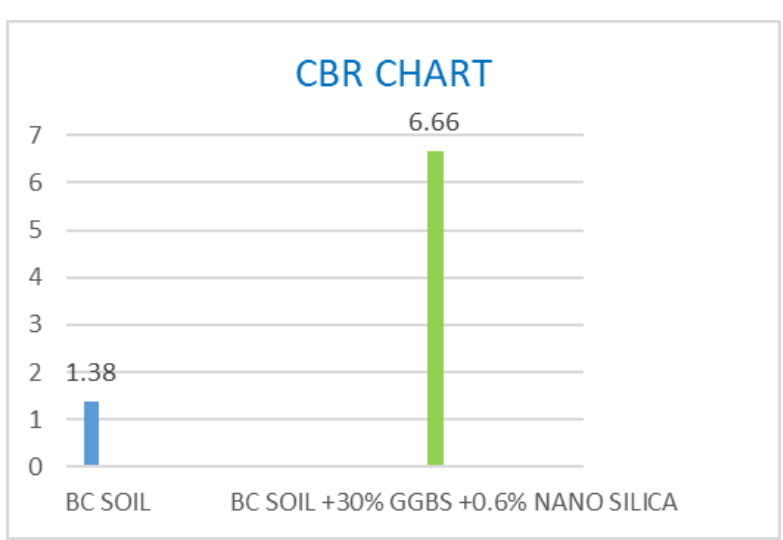

Fig. 9. CBR values of soil and soil, $30 \%$ GGBS \& $0.6 \%$ nano silica

The values are obtained from the above graph on seeing those readings the combination of soil, $30 \%$ of GGBS \& $0.6 \%$ nano silica gives higher CBR value than the combination of soil, $6 \%$ lime \& $0.6 \%$ nano silica so which combination gives the higher CBR value that combination considered.

7) Comparative study on UCS test

Table 10

UCS values at soil, $30 \%$ GGBS \& $0.6 \%$ nano silica

\begin{tabular}{|l|l|}
\hline \multicolumn{1}{|c|}{ Content } & UCS Value $\left(\mathbf{k g} / \mathbf{c m}^{2}\right)$ \\
\hline Soil $+0 \%$ of GGBS & 1.34 \\
\hline Soil $+30 \%$ of GGBS $+0.6 \%$ of nano silica & 6.11 \\
\hline
\end{tabular}

The values are obtained from the fig. 10, on seeing those readings the combination of soil, $30 \%$ of GGBS \& $0.6 \%$ nano silica gives higher UCS value than the combination of soil, $6 \%$ lime \& $0.6 \%$ nano silica so which combination gives the higher UCS value that combination considered. 


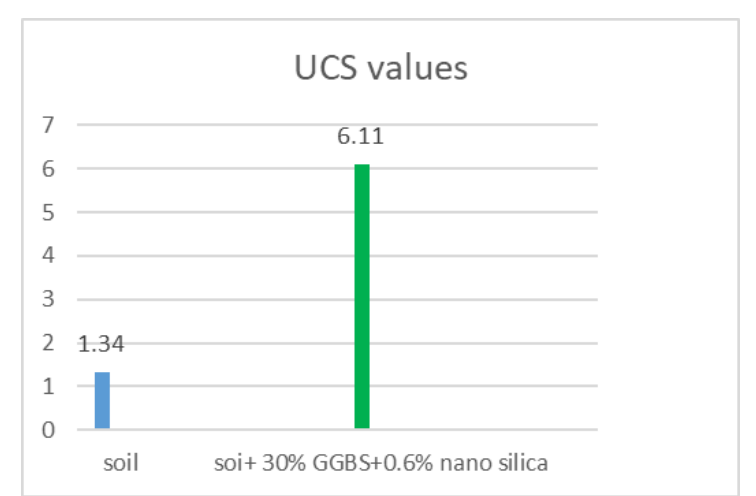

Fig. 10. UCS values at soil \& soil, $30 \%$ GGBS \& $0.6 \%$ nano silica

8) Comparative study on Free Swelling Index

Table 11

Free swelling index values at soil \& soil, 30\% GGBS \& $0.6 \%$ nano silica

\begin{tabular}{|l|l|}
\hline \multicolumn{1}{|c|}{ Content } & Free Swell Index Value (\%) \\
\hline Soil & 53.3 \\
\hline Soil + 30\% of GGBS +0.6\% nano silica & 18 \\
\hline
\end{tabular}

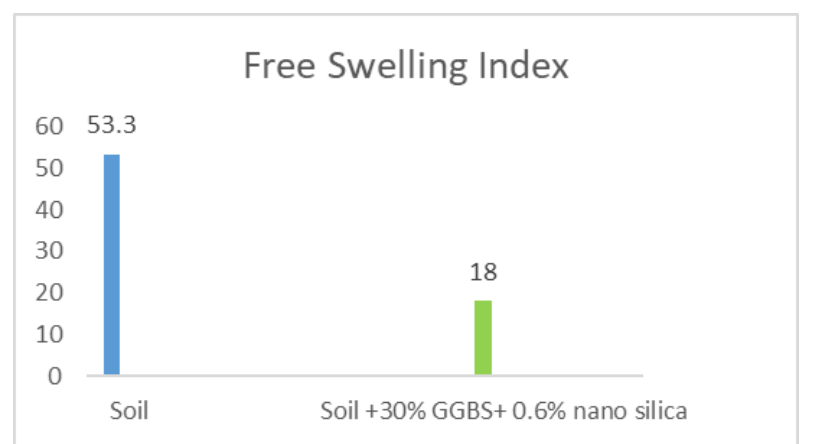

Fig. 11. Free swelling index values at soil \& soil, $30 \%$ GGBS \& $0.6 \%$ nano silica

The values are obtained from the fig. 11, on seeing those readings the combination of soil, $30 \%$ of GGBS \& $0.6 \%$ nano silica gives less FSI value than the combination of soil, $6 \%$ lime $\& 0.6 \%$ nano silica so which combination gives the less FSI value that combination considered for the project.

\section{Conclusion}

- Waste management is one of the industrial wastes can be done economically and efficiently.

- The combination of soil with $30 \%$ GGBS \& $0.6 \%$ nano silica gives more strength to black cotton soil.

- The combination of soil with $30 \%$ GGBS \& $0.6 \%$ nano silica reduces Optimum Moisture Content (OMC).

- It is observed that with increase of GGBS, more stability of soil is achieved.

- Finally, this study concluded that for the proportion of (BC soil + 30\% GGBS).

- The combination of soil with $30 \%$ GGBS \& $0.6 \%$ nano silica increase the Maximum dry density of black cotton soil (MDD).

- Stabilize the black cotton soil and increase the strength of soil and decrease the swelling pressure and decrease the fluid limit and plastic limit.

- At long last, this investigation presumed that for the proportion of (BC soil + 30\% GGBS).

- The combination of soil with $30 \%$ GGBS \& $0.6 \%$ nano silica increases the compressive strength value of black cotton soil.

- The combination of soil with $30 \%$ GGBS \& $0.6 \%$ nano silica reduces Free Swelling index of black cotton soil.

\section{References}

[1] I.S: 2720 (Part I)-1983: "Indian standard for preparation of dry soil samples for various tests", Bureau of Indian Standards Publications, New Delhi.

[2] I.S: 2720 (Part III/Section 1)-1980: "Indian standard for determination of specific gravity (fine grained soil)", Bureau of Indian Standards Publications, New Delhi.

[3] I.S: 2720 (Part III/Section 2)-1980: "Indian standard for determination of specific gravity (fine, medium and coarse grained soil)", Bureau of Indian Standards Publications, New Delhi.

[4] I.S: 2720 (Part IV)-1975: "Indian standard for grain size analysis", Bureau of Indian Standards Publications, New Delhi.

[5] I.S: 2720 (Part VII)-1980: "Indian standard for determination of water content- Dry density relationship using light compaction", Bureau of Indian Standards Publications, New Delhi.

[6] I.S: 2720 (Part XVI)-1965: "Indian standard for laboratory determination of CBR", Bureau of Indian Standards Publications, New Delhi.

[7] Tandel, and K. Yogendra, "Utilization of Copper Slag to improve geotechnical properties of soil", M. Tech. (SMFE) Thesis, SVNIT, Surat, 2008.

[8] B. C. Punamiya and A. K. Jain, "Soil mechanics and engineering property".

[9] C. E. G. Justo and S. K. Khanna, "Highway engineering".

[10] IS: 2720 (Part3/sec-1) 1980, "Code of practice for Determination of specific gravity," BIS, New Delhi.

[11] IS: 2720 (Part 5) 1970, "Code of practice for Determination of liquid \& plastic limit," BIS, New Delhi.

[12] IS: 2720 (Part 7) 1980, Determination of moisture content-dry density relation using lite compaction, BIS, New Delhi.

[13] IS: 2720 (Part 10) 1970, "Code of practice for Determination of Unconfined Compressive Strength".

[14] B. C. Punmia, Ashok. K. Jain, and A. K. Jain, "Soil mechanics and foundations." 